\title{
ANALISIS PENGARUH KUALITAS PRODUK, KUALITAS PELAYANAN TERHADAP LOYALITAS PELANGGAN PADA CAHAYA SWALAYAN MEUREUDU KABUPATEN PIDIE JAYA
}

\author{
Nyak Umar $^{(1)}$, T.Isnaini ${ }^{(2)}$, Nurul Husna ${ }^{(3)}$ \\ Fakultas Ekonomi Universitas Jabal Ghafur \\ Email : nyakumar@unigha.ac.id
}

\begin{abstract}
ABSTRAK
Penelitian ini bertujuan untuk mengetahui "Pengaruh Kualitas Produk dan Kualitas Pelayanan Terhadap Loyalitas Pelanggan Pada Cahaya Swalayan Meureudu Kabupaten Pidie Jaya".Dimana variabel independen yaitu Kualitas Produk(X1) dan Kualitas Pelayanan (X2)dan Loyalitas Pelanggan (Y) sebagai variabel dependennya.Populasi dalam penelitian ini adalah konsumen yang membeli padaCahaya Swalayan Meureudu Kabupaten Pidie Jayayang mana jumlahnya 100 Konsumen. Seluruh populasi dalam penelitian ini diambil sebagai Sampel. Data dikumpulkan dengan menggunakan metode survei melalui kuesioner yang diisi oleh responden.Kemudian data yang diperoleh dianalisis dengan menggunakan analisis regresi berganda. Analisis ini meliputi Uji Validitas, Uji Reliabilitas, Analisis Regresi berganda Uji Asumsi Klasik, Uji Hipotesis melalui Uji F dan Uji t, serta analisis Koefisien Determinasi $\left(\mathrm{R}^{2}\right)$. Berdasarkan hasil penelitian, diperoleh persamaan regresi.3. Variabel kualitas produk berpengaruh positif dan memiliki pengaruh yang paling dominan terhadap loyalitas pelanggan dengan koefisien regresi sebesar 0,495, Berdasarkan data responden dari ketiga indikator pertanyaan yang diajukan, dapat dilihat bahwa responden lebih dominan memberi tanggapan setuju. Berdasarkan Tabel dapat kita melihat bahwa nilai Cronbach Alpha untuk independent variable yaitu variabel Kualitas produk (X1) sebesar 0.881 atau $88,1 \%$, kualitas layanan (X2) sebesar 0.879 atau 87,9 dan untuk dependent variable yaitu Loyalitas pelanggan (Y) memiliki nilai cronbach alpha sebesar 0.882 atau 88,2\%.
\end{abstract}

Kata kunci :Kualitas Produk, Relationship Marketing, Loyalitas Pelanggan

\section{PENDAHULUAN}

Penelitian ini dilakukan pada Cahaya swalayan yang berlokasi dijalan Iskandar muda Meureudu Kabupaten Pidie Jaya. Cahaya swalayan berdiri pada tahun 2016. Lokasi yang strategis dan desain yang nyaman dengan tema vintage membuat konsumen yang mengunjungi merasa nyaman. Cahaya Swalayan juga menjual beragam produk-produk yang disukai masyarakat, pilihan produk juga beragam sehingga konsumen dapat memilih sesuai selera masing-masing.

Berdasarkan hasil wawancara, Cahaya swalayan mengalami pasang surut penjualan.
Penurunan penjualan yang cukup drastis dialami Cahaya swalayan pada sebelum bulan Desember tepatnya bulan September, namun pada waktu tertentu bisa mengalami penjualan yang tinggi dikarenakan faktor hari libur. Cahaya swalayan pada bulan Desember 2017 mengalami peningkatan penjualan mencapai Rp 86.400.000, kemudian setelah bulan Desember mengalami penurunan namun tidak drastis penurunannya karena hari libur telah usai. Persaingan yang ketat tentu sangat mempengaruhi naik-turunnya suatu aktivitas penjualan, tidak dapat dipungkiri bahwa banyak sekali swalayan besar maupun kecil yang khusus 
berkecimpung di usaha swalayan yang menjadi pesaing dari Cahaya swalayan. Kemungkinan adanya penjualan yang naikturun dari Cahaya swalayan adalah faktor kualitas produk dan kualitas pelayanan yang bagi konsumen tertentu kurang memuaskan, atau bisa juga dikarenakan konsumen yang sudah tidak loyal lagi dengan Cahaya swalayan.

Philip Kotler (2013:8) mendefinisikan pemasaran sebagai proses sosial dan managerial di mana individudan kelompok mendapatkan kebutuhan dan keinginan mereka dengan menciptakan, menawarkan dan menukarkan produk dan nilai dengan pihak lain. Pertukaran dari kedua belah pihak akan diukur dalam suatu ukuran yang disebut sebagai transaksi penjualan bagi suatu perusahaan kepada konsumen (pelanggan). Oleh karena itu terlihat bahwa penjualan merupakan salah satu bagian dari berbagai fungsi pemasaran.

Menurut Kasmir (2008:212), pemasaran merupakan usaha untuk memenuhi kebutuhan dan keinginan para nasabahnya terhadap produk dan jasa. Untuk mengetahui kebutuhan dan keinginan konsumen, maka setiap perusahaan perlu melakukan riset pemasaran, karena dengan melakukan riset pemasaran inilah bisa diketahui keinginan dan kebutuhan konsumen yang sebenarnya.

Kualitas produk menurut Kotler (2013:23) adalah kualitas didefinisikan sebagai keseluruhan ciri serta sifat barang dan jasa yang berpengaruh pada kemampuan memenuhi kebutuhan yang dinyatakan maupun yang tersirat. Lupiyoadi (2012:5) menyatakan konsep kualitas sendiri pada dasarnya bersifat relatif, yaitu tergantung dari sudut pandang yang digunakan untuk menentukan ciri-ciri dan spesifikasinya. Kualitas produk dapat disimpulkan dari penjelasan di atas yaitu keseluruhan barang dan jasa yang berkaitan dengan keinginan konsumen yang dari segi keunggulan produk telah memenuhi syarat untuk diperjualkan sesuai harapan dari pelanggan.
Pelayanan adalah setiap tindakan atau kegiatan yang dapat ditawarkan oleh suatu pihak kepada pihak lain, yang pada dasarnya tidak berwujud dan tidak mengakibatkan kepemilikan apapun. Kotler (2010:83). Tjiptono (2013:65) menyatakan kualitas pelayanan adalah tingkat keunggulan yang diharapkan dan pengendalian atas tingkat keunggulan tersebut untuk memenuhi keinginan pelanggan. Kualitas pelayanan mendorong pelanggan untuk komitmen kepada produk dan pelayanan suatu perusahaan sehingga berdampak kepada peningkatan market share suatu produk. Kualitas pelayanan sangat krusial dalam mempertahankan pelanggan dalam waktu yang lama. Perusahaan yang memiliki pelayanan yang superior akan dapat memaksimalkan performa keuangan perusahaan (Gilbert, 2013:76).

Loyalitas pelanggan adalah komitmen pelanggan terhadap suatu merek, toko atau pemasok berdasarkan sifat yang sangat positif dalam pembelian jangka panjang(Tjiptono, 2013:74). Perusahaan yang mempunyai pelanggan lama yang tetap loyal, tidak perlu melakukan proses edukasi untuk meyakinkan mereka membeli atau menggunakan produk kita, namun yang perlu kita lakukan adalah menginformasikan apabila ada produk baru yang sesuai dengan kebutuhan mereka dan menjaga hubungan bisnis yang sudah tercipta. Perusahaan dalam upaya untuk mempertahankan pelanggan harus mendapatkan prioritas yang lebih besar dibandingkan untuk mendapatkan pelanggan baru.Loyalitas pelanggan berdasarkan kepuasan murni dan terus-menerus merupakan salah satu aset terbesar yang mungkin didapat oleh perusahaan.

\section{METODE PENELITIAN}

\section{Lokasi Dan Objek Penelitian}

Untuk mengetahui dan informasi dalam menyelesaikan skripsi ini, penulis mengadakan serangkain langsung pada lokasi penelitian yaitu di Cahaya Swalayan Meureudu yang berada di Jalan Iskandar 
Muda Kecamatan Meureudu Kabupaten Pidie Jaya, penelitian ini dilakukan yaitu untuk memperoleh gambaran tentang pengaruh kualitas produk dan layanan terhadap loyalitas pelanggan pada Cahaya Swalayan Meureudu Kabupaten Pidie Jaya.

Objek yang diteliti dalam penelitian ini adalah seluruh konsumen konsumen pada Cahaya Swalayan Kecamatan Meureudu Kabupaten Pidie Jaya. Jenis data primer dibutuh kan dalam penelitian ini adalah berupa kumpulan informasi yang diperoleh dengan metode wawancara dan menggunakan kuesioner terstuktur yang diberikan kepada konsumen pada Cahaya Swalayan Meureudu Kabupsten Pidie Jaya.

\section{Populasi dan Sampel}

Populasi adalah wilayah generalisasi yang terdiri atas obyek atau subyek yang mempunyai kualitas dan karakteristik tertentu yang ditetapkan oleh peneliti untuk dipelajari dan kemudian ditarik kesimpulannya (Sugiyono, 2009:90). Populasi juga diartikan sebagai sekumpulan unsur yang menjadi objek penelitian.

Populasi pada penelitian ini adalah seluruh masyarakat meureudu yang membeli pada Cahaya Swalayan jalan iskandar muda Meureudu kabupaten pidie jaya sebagai populasi. Prosedur yang digunakan untuk pengumpulan data adalah tehnik probability sampling,yaitu tehnik sampling yang memberikan peluang yang sama bagi setiap unsur (Anggota) populasi untuk dipilih untuk menjadi sampel.

Teknik pengambilan sampel dalam penelitian ini menggunakan teknik purposive sampling, artinya dalam pengambilan sampel menggunakan teknik dengan pertimbangan tertentu, yaitu pertimbangan yang mempertimbangkan siapa saja yang pernah berbelanja pada Cahaya swalayan sebagai sampel penelitiannya.Akunto (2010:34) menyatakan sampel penelitian merupakan sebagian dari populasi yang diambil sebagai sumber data dan dapat mewakili seluruh populasi.Sampel juga diartikan sebagai bagian dari karakteristik yang dimiliki oleh populasi.

Cara penentuan ukuran sampel dilakukan menggunakan rumus Slovin (Sugiyono, 2011:56) sebagai berikut:

$$
n=\frac{z^{2}}{4 \mu^{2}}
$$

Dimana

n : Jumlah Sampel

$\mathrm{Z}$ : tingkat keyakinan sampel yang

dibutuhkan dalam penelitian (pada $\alpha=5 \%$ atau derajat keyakinan ditentukan

95\% maka $Z=1,96$ )

: margin of error, tingkat kesalahan yang dapat ditolerir (ditentukan 10\%)

Berdasarkan rumus di atas, maka perhitungan penentuan ukuran sampel pada penelitian ini adalah sebagai berikut:

$$
n=\frac{1,96^{2}}{4(0,1)^{2}}=96,04
$$

Jumlah sampel yang digunakan dalam penelitian ini, apabila mengacu pada penghitungan jumlah minimal sampel yang ada adalah berjumlah 96 responden.

\section{Tehnik Pengumpulan Data}

Jenis data pada penelitian ini menggunakan data primer.Data primer menurut Indriantoro dan Supomo (2010:78) adalah data penelitian yang diperoleh secara langsung dari sumber data yang dikumpulkan secara khusus dan berhubungan langsung dengan masalah yang diteliti. Data primer ini didapat melalui cara menyebar kuesioner dan kemudian diolah data, dengan Cahaya Swalayan Meureudu sebagai objek penelitian ini.

Selain diperoleh data melalui kuesioner ,juga diperolrh data pendukung yang didapatkan melalui:

1. Wawancara;Moleong (2011:135) menjelaskan bahwa wawancara adalahpercakapan dengan maksudmaksud tertentu. Peneliti dan responden berhadapan langsung (face to face) untuk 
mendapatkan informasi secara lisan dengan tujuan mendapatkan data yang dapat menjelaskan permasalahan penelitian. Wawancara yang dilakukan dalam penelitian adalah antara peneliti dengan pemilik Cahaya Swalayan

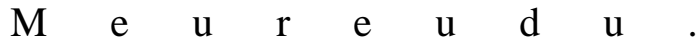

2. Penelitian perpustakaan; Studi kepustakaan adalah teknik pengumpulan data dengan mengadakan penelaahan terhadap buku-buku, literatur-literatur, catatan-catatan, dan laporan-laporan yang ada hubungannya dengan masalah yang dipecahkan. (Nazir, 2009:11). Studi kepustakaan juga dapat diartikan sebagai upaya peneliti dalam mencari informasi mengenai topik yang relevan dengan permasalahan yang diteliti yang terdapat di dalam buku, literatur, jurnal, tesis dan disertasi, karya ilmiah, ensiklopedia, maupun sumber tertulis lainnya.

\section{Tehnik Analisis Data}

Analisis yang digunakan dalam penelitian ini adalah analisis regresi linear berganda (multiple regression). Analisis regresi linear berganda digunakan untuk menganalisis pengaruh antara variabel independen (kualitas produk, kualitas pelayanan dan nilai pelanggan) terhadap variabel dependen yaitu kepuasan pelanggan. Rumus matemastis dari regresi linear berganda yang diganakan dalam penelitian ini adalah :

$\mathrm{Y}=\mathrm{a}+\mathrm{b} 1 \mathrm{X} 1+\mathrm{b} 2 \mathrm{X} 2+\mathrm{e}$

Keterangan : $\mathrm{Y}=$ Kepuasan Pelanggan

$\begin{array}{ll}\mathrm{a} & =\text { Konstanta } \\ \mathrm{b} & =\text { Koefisien regresi } \\ \mathrm{X} 1 & =\text { Kualitas Produk } \\ \mathrm{X} 2 & =\text { Kualitas Pelayanan } \\ \mathrm{e} & =\text { error disturbances }\end{array}$

\section{Pengujian Hipotesis}

Pengujian hipotesis dapat dilakukan dengan metode statistik, yaitu melalui pengukuran nilai koefisien determinasi, nilai statistik $F$ dan nilai statistik t. Menurut
Ghozali (2009:88), perhitungan statistik disebut signifikan secara statistik apabila nilai uji statistiknya berada dalam daerah kritis (daerah dimana Ho ditolak). Sebaliknya perhitungan statistik disebut tidak signifikan apabila nilai uji statistiknya berada dalam daerah dimana Ho diterima.

\section{Uji Persial (Uji t)}

Uji $t$ digunakan untuk menguji signifikansi konstanta dari setiap variabel independen, apakah variabel kualitas produk (X1), kualitas pelayanan (X2), benar - benar berpengaruh secara parsial (terpisah) terhadap variabel dependennya yaitu loyalitas pelanggan (Y). Hipotesis yang dipakai :

1) $\mathrm{HO}: \mathrm{bi}=0$

Artinya : variabel independen tidak berpengaruh terhadap variabel dependen.

2) $\mathrm{H} 1:$ bi $>0$

Artinya : variabel independen berpengaruh positif terhadap variabel dependen

Kriteria pengujian dengan tingkat signifikansi $(\alpha)=0,05$ ditentukan sebagai berikut :

1) thitung $<$ ttabel, maka HO diterima

2) thitung > ttabel, maka H0 ditolak

\section{Uji Simultan (uji f)}

Kualitas produk (X1), kualitas pelayanan (X2), dan Loyalitas pelanggan (Y). Kriteria untuk menguji hipotesis adalah

a. Membuat hipotesis untuk kasus pengujian F-test di atas, yaitu :

1) $\mathrm{H} 0: \mathrm{b} 1=\mathrm{b} 2=\mathrm{b} 3=0$

Artinya : tidak ada pengaruh yang signifikan dari variabel bebas yaitu kualitas produk (X1), kualitas pelayanan (X2), dan loyalitas pelanggan $(\mathrm{Y})$.

2) $\mathrm{H} 1: \mathrm{b} 1-\mathrm{b} 3>0$

Artinya : ada pengaruh yang signifikan dari variabel bebas yaitu kualitas produk (X1), kualitas pelayanan (X2), dan loyalitas pelanggan $(\mathrm{Y})$. 
b. Menentukan F tabel dan F hitung. Dengan tingkat kepercayaan sebesar 95 $\%$ atau taraf signifikansi sebesar $5 \%$, maka :

1) Jika $\mathrm{F}$ hitung $>\mathrm{F}$ tabel, maka $\mathrm{H} 0$ ditolak, berarti masing-masing variabel bebas secara bersama-sama mempunyai pengaruh yang signifikan terhadap variabel terikat.

2) Jika F hitung < F tabel, maka $\mathrm{H} 0$ diterima, berarti masing-masing variabel bebas secara bersama-sama tidak mempunyai pengaruh yang signifikan terhadap variabel terikat.

\section{HASIL PENELITIAN DAN} PEMBAHASAN

Penjelasan Responden Terhadap variabel Kualitas produk (X1)

Untuk mengetahui lebih rinci mengenai tanggapan responden terhadap variabel kualitas produk (X1) dapat dilihat pada tabel 4.2 .

Tabel 4.2

Tanggapan Responden Terhadap Variabel

\begin{tabular}{|c|c|c|c|c|c|c|c|c|c|c|c|c|}
\hline \multicolumn{13}{|c|}{ Kualitas Produk (X1) } \\
\hline \multirow{2}{*}{ No } & \multirow{2}{*}{ Indikator } & \multicolumn{2}{|c|}{\begin{tabular}{|l}
$\begin{array}{l}\text { Sgt } \\
\text { Setuju }\end{array}$ \\
\end{tabular}} & \multicolumn{2}{|c|}{\begin{tabular}{|l} 
Tdk \\
Setuju
\end{tabular}} & \multirow{2}{*}{\multicolumn{2}{|c|}{\begin{tabular}{|l|l} 
Krg \\
Setuju
\end{tabular}}} & \multicolumn{2}{|c|}{ Setuju } & \multicolumn{2}{|c|}{ Sgt Setuju } & \\
\hline & & \begin{tabular}{|l}
$\mathrm{Fr}$ \\
$\mathrm{Fr}$
\end{tabular} & $\%$ & & $\%$ & & & $\begin{array}{ll}\mathrm{Fr} \\
\end{array}$ & & & $\%$ & \\
\hline 1. & X1.1 &. & & & & & & 65 & 67.7 & 31 & 32.3 & 4.32 \\
\hline 2. & $\mathrm{X} 1.2$ & & & & & & - & 63 & \begin{tabular}{|l|}
65.6 \\
\end{tabular} & 33 & \begin{tabular}{|l|}
34.4 \\
\end{tabular} & 4.34 \\
\hline 3. & $\mathrm{X} 1.3$ & . & & - & - & & . & 65 & \begin{tabular}{|l|} 
\\
\end{tabular} & 31 & 32.3 & 4.32 \\
\hline Kere & & & & & & & & & & & & 4.32 \\
\hline
\end{tabular}

Sumber: Data Primer, 2019 (diolah)

Berdasarkan tabel di atas juga dapat di jelaskan bahwa pernyataan responden terhadap variabel kualitas produk dapat di jelaskan bahwa pernyataan mengenai variasi produk di peroleh nilai rata-rata 4,32, pernyataan mengenai rasa sesuai dengan harapan di peroleh nilai rata-rata 4,34, pernyataan mengenai produk higienis di peroleh nilai rata-rata 4,32 .

Hasil penelitian terhadap variabel kualitas produk di peroleh nilai rerata sebesar
4,32 yang bermakna bahwa responden dalam penelitian ini menyatakan setuju bahwa kualitas produk berpengaruh terhadap loyalitas pelanggan pada cahaya swalayan Meureudu Kabupaten Pidie Jaya.

\section{Penjelasan Responden Terhadap Variabel Kualitas layanan (X2)}

Untuk mengetahui lebih rinci mengenai tanggapan responden terhadap varaibel kualitas layanan (X2) dapat dilihat pada tabel 4.3.

Tabel 4.3

Tanggapan Responden Terhadap Variabel

\begin{tabular}{|c|c|c|c|c|c|c|c|c|c|c|c|c|}
\hline \multirow{2}{*}{ No } & \multirow{2}{*}{ Indikator } & \multicolumn{2}{|c|}{ Sgt Tdk Setuju } & \multicolumn{2}{|c|}{$\begin{array}{l}\text { Tdk } \\
\text { Setuju }\end{array}$} & \multicolumn{2}{|c|}{\begin{tabular}{|l|l}
$\mathrm{Krg}$ \\
Setuju
\end{tabular}} & \multicolumn{2}{|c|}{ Setuju } & \multicolumn{2}{|c|}{ Sgt Setuju } & \multirow{2}{*}{$\begin{array}{l}\text { Rata } \\
\text { Rata } \\
\end{array}$} \\
\hline & & $\mathrm{Fr}$ & $\%$ & $\mathrm{Fr}$ & $\%$ & $\mathrm{Fr}$ & $\%$ & Fr & $\%$ & Fr & $\%$ & \\
\hline 1. & $\mathrm{X} 2.1$ & - & - & - & - & - & - & 64 & 66.7 & 32 & 33.3 & 4.33 \\
\hline 2. & $\mathrm{X} 2.2$ & - & . & - & - & - & - & 63 & 65.6 & 33 & 34.4 & 4.34 \\
\hline 3. & $\mathrm{X} 2.3$ & - & . & . & - & . & . & 65 & 67.7 & 31 & 32.3 & 4.32 \\
\hline \multicolumn{12}{|c|}{ Rerat } & 4.33 \\
\hline
\end{tabular}

Sumber: Data Primer, 2019 (diolah)

Berdasarkan tabel di atas juga dapat di jelaskan bahwa pernyataan responden terhadap variabel kualitas layanan dapat di jelaskan bahwa pernyataan pelayanan yang tepat di peroleh nilai rata-rata 4,33, pernyataan mengenai respon karyawan di peroleh nilai rata-rata 4,34 , pernyataan mengenai kemudahan komunikasi di peroleh nilai rata-rata 4.32 .

Hasil penelitian terhadap variabel kualitas layanan di peroleh nilai rerata sebesar 4.33 yang bermakna bahwa responden dalam penelitian ini menyatakan setuju bahwa kualitas layanan berpengaruh terhadap terhadap loyalitas pelanggan pada cahaya swalayan Meureudu Kabupaten Pidie Jaya.

\section{Penjelasan Responden Terhadap Variabel Loyalitas Pelanggan (Y)}

Untuk mengetahui lebih rinci mengenai tanggapan responden terhadap varaibel 
Jurnal Sosial Humaniora Sigli (JSH)

p ISSN : 2615-3688

$e$ ISSN : 2716-0270

http://journal.unigha.ac.id/index.php/JSH

loyalitas pelanggan(Y) dapat dilihat pada tabel 4.4.

Tabel 4.4

Tanggapan Responden Terhadap Variabel Loyalitas pelanggan (Y)

\begin{tabular}{|c|c|c|c|c|c|c|c|c|c|c|c|c|}
\hline \multirow[t]{2}{*}{ No } & \multirow[t]{2}{*}{ Indikator } & \multicolumn{2}{|c|}{\begin{tabular}{|lr} 
Sgt Tdk \\
Setuju
\end{tabular}} & \multicolumn{2}{|c|}{\begin{tabular}{|l|} 
Tdk \\
Setuju \\
\end{tabular}} & \multicolumn{2}{|c|}{\begin{tabular}{|l|}
$\mathrm{Krg}$ \\
$\mathrm{Setuju}$ \\
\end{tabular}} & \multicolumn{2}{|c|}{ Setuju } & \multicolumn{2}{|c|}{ Sgt Setuju } & \multirow{2}{*}{$\begin{array}{l}\text { Rata } \\
\text { Rata } \\
\text { Rata }\end{array}$} \\
\hline & & $\mathrm{Fr}$ & $\%$ & $\begin{array}{ll}\mathrm{Fr} \\
\end{array}$ & $\%$ & $\mathrm{Fr}$ & $\%$ & $\mathrm{Fr}$ & $\%$ & $\mathrm{Fr}$ & $\%$ & \\
\hline 1. & Y1 & - & - & - & - & - & - & 63 & 65.6 & 33 & 34.4 & 4.34 \\
\hline 2. & Y2 & - & - & - & - & - & - & 62 & 64.6 & 34 & 35.4 & 4.35 \\
\hline 3. & Y3 & - & - & - & - & - & - & 63 & 65.6 & 33 & 34.4 & 4.34 \\
\hline \multicolumn{12}{|c|}{ Rerata } & 4.34 \\
\hline
\end{tabular}

Sumber : Data Primer, 2019 (diolah)

Berdasarkan tabel di atas juga dapat di jelaskan bahwa pernyataan responden terhadap variabel loyalitas pelanggan dapat di jelaskan bahwa pernyataan mengenai Mengatakan hal positifdi peroleh nilai ratarata 4,34, pernyataan mengenai pembelian ulang di peroleh nilai rata-rata 4,35, pernyataan mengenai merekomendasikan di peroleh nilai rata-rata 4,34 .

Hasil penelitian terhadap variabel loyalitas pelanggan di peroleh nilai rerata sebesar 4.34 yang bermakna bahwa responden dalam penelitian ini menyatakan setuju bahwa faktor kualitas produk dan kuliatas layanan dapat berpengaruh terhadap loyalitas pelanggan pada cahaya swalayan Meureudu Kabupaten Pidie Jaya.

\section{Uji Validitas dan Realibilitas Uji Validitas}

Uji validitas digunakan untuk mengukur sah atau valid tidaknya suatu kuesioner.Suatu kuesioner dikatakan valid jika pertanyaan pada kuesioner mampu untukmengungkapkan sesuatu yang akan diukur oleh kuesioner tersebut (Ghozali, 2009:23).Dalam hal ini digunakan beberapa butir pertanyaan yang dapat secara tepatmengungkapkan variabel yang diukur tersebut. Setiap faktor dianggap valid jika menghasilkan Pearson Correlation diatas 0,50 menunjukkan bahwa indikator-indikator tersebut merupakan suatu kesatuan alat ukur yang mampu mengukur suatu konstruk yang sama dan dapat memprediksi apa yang seharusnya dapat di prediksi hal ini sependapat dengan (Nunnaly, 2009:45). Uji Validitas ini dapat dilihat pada tabel 4.5.

Tabel 4.5

Validitas Indikator Variabel

\begin{tabular}{|c|c|c|c|c|}
\hline \multicolumn{2}{|c|}{$\begin{array}{l}\text { No. } \\
\text { Pernyataa } \\
\text { n }\end{array}$} & $\begin{array}{l}\text { Variabe } \\
\text { I }\end{array}$ & $\begin{array}{l}\text { Kosfisie } \\
\text { n } \\
\text { korelasi }\end{array}$ & Ket \\
\hline 1. & $\mathrm{X}_{1.1}$ & \multirow{3}{*}{$\begin{array}{l}\text { Kualitas } \\
\text { produk } \\
\text { (X1) }\end{array}$} & 0.984 & \multirow{3}{*}{$\begin{array}{l}\text { Vali } \\
\text { d }\end{array}$} \\
\hline 2. & $\mathrm{X}_{1.2}$ & & 0.969 & \\
\hline 3. & $\mathrm{X}_{1.3}$ & & 0.952 & \\
\hline 1. & $\mathrm{X}_{2.1}$ & \multirow{3}{*}{$\begin{array}{l}\text { Kualitas } \\
\text { layanan } \\
(\mathrm{X} 2)\end{array}$} & 0.979 & \multirow{3}{*}{$\begin{array}{l}\text { Vali } \\
\text { d }\end{array}$} \\
\hline 2. & $X_{2.2}$ & & 0.956 & \\
\hline 3. & $\mathrm{X}_{2.3}$ & & 0.938 & \\
\hline 1. & $Y_{1}$ & \multirow{3}{*}{$\begin{array}{l}\text { Loyalita } \\
\text { s } \\
\text { pelangga } \\
\text { n (Y) }\end{array}$} & 0.977 & \multirow{3}{*}{$\begin{array}{l}\text { Vali } \\
\text { d }\end{array}$} \\
\hline 2. & $Y_{2}$ & & 0.969 & \\
\hline 3. & $Y_{3}$ & & 0.961 & \\
\hline
\end{tabular}

Sumber : Data Primer, 2019 (diolah)

Berdasarkan tabel diatas dapat di jelaskan bahwa semua variabel yang digunakan dalam penelitian ini semuanya dinyatakan valid, karena mempunyai koefisien korelasi di atas dari nilai kritis korelasi product moment yaitu sebesar 0.361 sehingga semua pertanyaan yang terkandung dalam kuesioner penelitian ini dinyatakan valid untuk dilanjutkan penelitian yang lebih mendalam.

\section{Uji Reliabilitas}

Uji Reliabilitas menunjukkan konsistensi dan stabilitas dari suatu skor (skala pengukuran). Suatu instrumen dapat memiliki tingkat kepercayaan yang tinggi (konsisten) atau stabil dari waktu ke waktu (Ghozali, 2009:34). Acuan tingkat reliabilitas yang di gunakan dalam penelitian ini merujuk pada pendapat Ghozali (2009:35) yang menunjukkan bahwa konstruk atau variabel dapat dikatan reliabel jika memilik nilai Cronbach Alpha > 0,60.

\section{Tabel 4.6}

Reliabilitas Indikator Variabel (Alpha)

\begin{tabular}{|c|l|l|l|l|}
\hline $\begin{array}{c}\text { N } \\
\mathbf{O}\end{array}$ & Variabel & $\begin{array}{c}\text { Item } \\
\text { Variabe } \\
\text { I }\end{array}$ & $\begin{array}{c}\text { Nilai } \\
\text { Alph } \\
\mathbf{a}\end{array}$ & $\begin{array}{c}\text { Kehandala } \\
\text { n }\end{array}$ \\
\hline $\mathbf{1}$ & $\begin{array}{l}\text { Kualitas } \\
\text { produk } \\
\left(\mathrm{X}_{1}\right)\end{array}$ & 3 & 0.881 & Handal \\
\hline $\mathbf{2}$ & $\begin{array}{l}\text { Kualitas } \\
\text { layanan } \\
\left(\mathrm{X}_{2}\right)\end{array}$ & 3 & 0.879 & Handal \\
\hline & $\begin{array}{l}\text { Loyalitas } \\
\text { pelangga } \\
\text { n(Y) }\end{array}$ & 3 & 0.882 & Handal \\
\hline
\end{tabular}

Sumber : Data Primer, 2019 (diolah) 


\begin{abstract}
Berdasarkan Tabel dapat kita melihat bahwa nilai Cronbach Alpha untuk independent variable yaitu variabel Kualitas produk (X1) sebesar 0.881 atau $88,1 \%$, kualitas layanan (X2) sebesar 0.879 atau 87,9 dan untuk dependent variable yaitu Loyalitas pelanggan (Y) memiliki nilai cronbach alpha sebesar 0.882 atau $88,2 \%$. Dengan demikian pengukuran reliabilitas terhadap variabel penelitian menunjukkan bahwa pengukuran kehandalan memenuhi kredibilitas Cronbach Alpha dimana nilai alphanya lebih besar dari Alpha 0,60\%.
\end{abstract}

\section{Uji Asumsi Klasik \\ Uji Normalitas}

Uji normalitas digunakan untuk menguji apakah dalam model regresi, variable pengganggu atau residual memiliki distribusi normal (Ghozali, 2009:36). Ada dua cara untuk mendetekeksi apakah residual berdistribusi normal atau tidak yaitu dengan analisis gambar berupa plot dan uji statistik. Berikut adalah hasil dari olah data yang dilakukan dari uji normalitas, dapat dilihat pada gambar 4.1 berikut:

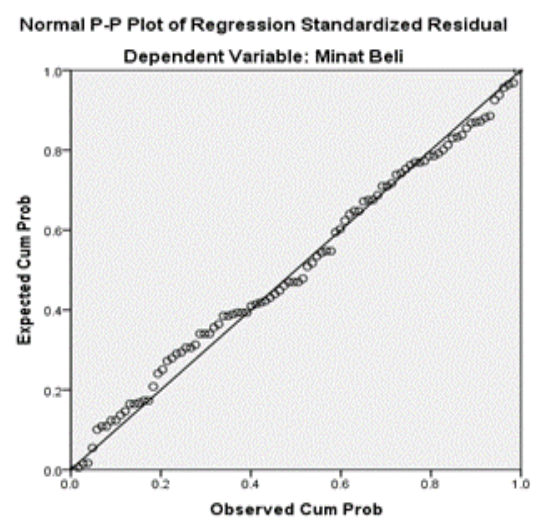

Gambar 4.1 Normal P-Plot (Hasil Penelitian, 2019)

Setelah melihat hasil Gambar 4.1 Normal P-Plot maka dapat disimpulkan bahwa model regresi memenuhi asumsi normalitas karena pada grafik normal P-Plot rerlihat titik-titik mendekati garis dan menyebar disekitar garis diagonal dan menunjukkan hasil yang sangat signifikan.

\section{Uji Multikolinieritas}

Menurut Ghozali (2009:37) Uji Multikolinieritas bertujuan untuk menguji dalam model regresi ditemukan adanya korelasi antar variabel-variabel bebas. Model regresi yang baik seharusnya tidak terjadi korelasi diantara variabel independen. Uji ini dilakukan dengan melihat Tolerance dan Variance Inflation factor (VIF). Nilai Tolerance yang rendah sama dengan nilai VIF yang tinggi karena VIF $=1 /$ Tolerance) .

Jika nilai tolerance atau nilai Variance inflaction Factor (VIF) $>0,10$ berarti dapat di simpulkan adanya multikolinearitas. Namun sebaliknya jika hasil perhitungan nilai nilai tolerance atau nilai Variance inflaction Factor (VIF) $<0,10$ maka dapat disimpulkan bahwa tidak terjadi multikolinearitas antar variabel independent.

Untuk melihat hasil dari olah data uji multikoliearitas dapat dilihat pada tabel 4.7berikut ini:

Tabel 4.7 Uji Multikolinieritas

Coefficients $^{\mathrm{a}}$

\begin{tabular}{|c|c|c|c|c|c|c|c|}
\hline \multirow[t]{2}{*}{ Model } & \multicolumn{2}{|c|}{$\begin{array}{l}\text { Unstanda } \\
\text { rdized } \\
\text { Coefficie } \\
\text { nts } \\
\end{array}$} & $\begin{array}{l}\text { Standar } \\
\text { dized } \\
\text { Coeffici } \\
\text { ents }\end{array}$ & \multirow[b]{2}{*}{$\mathrm{t}$} & \multirow[b]{2}{*}{$\begin{array}{l}\mathrm{Si} \\
\mathrm{g} .\end{array}$} & \multicolumn{2}{|c|}{$\begin{array}{l}\text { Collinearit } \\
\text { y Statistics }\end{array}$} \\
\hline & B & $\begin{array}{l}\text { Std. } \\
\text { Erro } \\
\text { r }\end{array}$ & Beta & & & $\begin{array}{l}\text { Toler } \\
\text { ance }\end{array}$ & $\begin{array}{l}\text { VI } \\
\text { F }\end{array}$ \\
\hline $\begin{array}{l}1 \text { (Cons } \\
\text { tant) }\end{array}$ & $\begin{array}{l}2, \\
29 \\
4\end{array}$ &, 931 & & $\begin{array}{l}2, \\
46 \\
5\end{array}$ & $\begin{array}{l}0 \\
1 \\
6\end{array}$ & & \\
\hline$\times 1$ & $\begin{array}{l}5 \\
02\end{array}$ & 108 & 495 & $\begin{array}{l}4, \\
65 \\
8\end{array}$ & $\begin{array}{l}0 \\
0 \\
0\end{array}$ & ,387 & $\begin{array}{l}2 \\
58 \\
6\end{array}$ \\
\hline $\mathrm{X} 2$ & $\begin{array}{l}, 3 \\
25\end{array}$ & 109, & ,318 & $\begin{array}{l}2, \\
99 \\
2\end{array}$ & $\begin{array}{l}0 \\
0 \\
4\end{array}$ & ,387, & $\begin{array}{l}2, \\
58 \\
6\end{array}$ \\
\hline
\end{tabular}

Dari Tabel 4.7 dapat di lihat nilai tolerance dan nilai VIF, untuk ketiga variabel.Nilai tolerance untuk variabel $\mathrm{X} 1$ (Kualitas produk) sebesar 0.387, nilai tolerance untuk X2 (kualitas layanan) sebesar 0.387. Sedangkan untuk nilai VIF Variabel $\mathrm{X} 1$ (Kualitas produk) sebesar 2,586, nilai VIF untuk Variabel X2 (kualitas layanan) sebesar 2,586. Karena nilai $\mathrm{VIF}<10$ dan nilai tolerance> 0.10 maka dapat disimpulkan bahwa pada model regresi tidak ditemukan 
Jurnal Sosial Humaniora Sigli (JSH)

p ISSN : 2615-3688

$e$ ISSN : 2716-0270

http://journal.unigha.ac.id/index.php/JSH

adanya masalah multikolinearitas antar variabel-variabel yang diteliti.

\section{Uji Heteroskedastisitas}

Ghozali (2009:38), menyatakan bahwa pengujian heteroskedastisitas bertujuan untuk mengetahui apakah di dalam model regresi terjadi ketidaksamaan dari variance dan residual atau pengamatan lainnya. Jika Variance dan residual suatu pengamatan ke pengamatan yang lain tetap maka disebut homoskedastisitas, jika berbeda disebut heteroskedastisitas. Untuk melihat heteroskedastisitas, peneliti menggunakan atau melihat grafik scatterplot antara lain prediksi variabel independen (ZPRED) dengan residuanya (SRESID). Jika terbentuk pola tertentu maka terjadi heteroskedastisitas tetapi jika titik-titik dalam gambar tersebar ke seluruh arah maka tidak terjadi heteroskedastisitas. Untuk lebih jelasnya berikut adalah gambar dari hasil oleh data uji heteroskedastisitas:

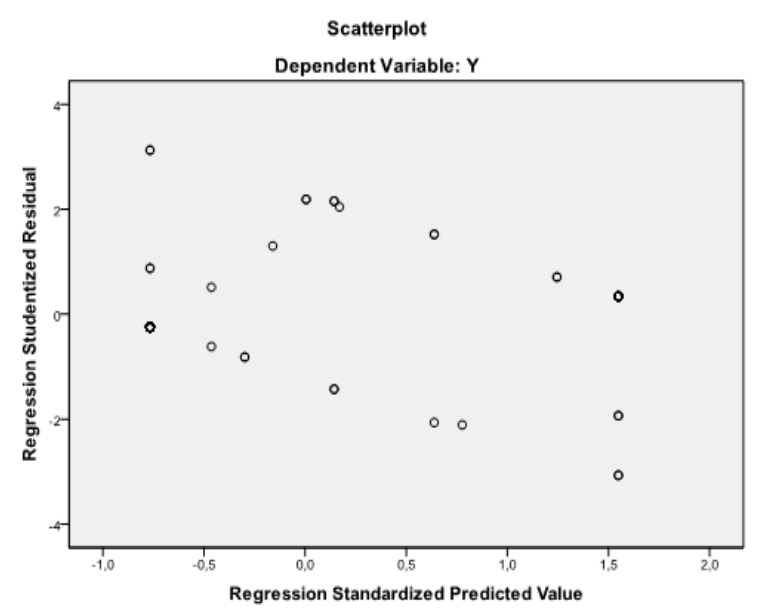

Gambar 4.2 Uji Heteroskedastisitas Sumber : Hasil penelitian, 2019

Berdasarkan gambar 4.2 dapat dilihat bahwa titik-titik tersebar ke berbagai arah, baik diatas maupun bawah angka 0 pada sumbu Y dan tidak membentuk pola tertentu. Jadi dapat disimpulkan bahwa tidak terjadi heteroskedastisitas pada model regresi sehingga layak dipakai untuk memprediksi loyalitas pelanggan pada cahaya swalayan Meureudu Kabupaten Pidie Jaya.

\section{Uji Regresi Linear berganda}

Uji regresi linear berganda ini di lakukan untuk mengetahui ada tidaknya pengaruh variabel kualitas produk dan kualitas layanan terhadap loyalitas pelanggan.Adapun hasil olahan data dengan menggunakan SPSS versi 18 dapat dilihat pada tabel 4.8 .

Tabel 4.8

Hasil Perhitungan Regresi Linearitas

Berganda

\begin{tabular}{|c|c|c|c|c|c|c|c|}
\hline \multirow[t]{2}{*}{ Model } & \multicolumn{2}{|c|}{$\begin{array}{l}\text { Unstandardized } \\
\text { Coefficients }\end{array}$} & \multirow{2}{*}{\begin{tabular}{|l|}
$\begin{array}{l}\text { Standardized } \\
\text { Coefficients }\end{array}$ \\
Beta \\
\end{tabular}} & \multirow[b]{2}{*}{ t } & \multirow[b]{2}{*}{ Sig. } & \multicolumn{2}{|c|}{$\begin{array}{l}\text { Collinearity } \\
\text { Statistics }\end{array}$} \\
\hline & B & Std. Error & & & & $\begin{array}{l}\text { Tolera } \\
\text { nce }\end{array}$ & VIF \\
\hline 1 (Constant) & 2,294 &, 931 & & 2,465 & ,016 & & \\
\hline$X_{1}$ & ,502 &, 108 & ,495 & 4,658 &, 000 & , 387 & 2,586 \\
\hline X2 & .325 &, 109 &, 318 & 2,992 & .004 & .387 & 2,586 \\
\hline
\end{tabular}

Untuk model persamaan regresi Standardized Coefficients, nilai koefisiennya adalah sebagai berikut:

$$
\mathrm{Y}=0.495 \mathrm{X} 1+0.318 \mathrm{X} 2
$$

1. Koefisien regresi $(\beta) \mathrm{X} 1$ sebesar 0,495 memberikan arti bahwa kualitas produk (X1) berpengaruh positif terhadap loyalitas pelanggan pada cahaya swalayan Meureudu Kabupaten Pidie Jaya. (Y). Hal ini menunjukkan bahwa setiap perubahan 1 satuan kualitas produk, maka akan terjadi peningkataan sebesar 0,495 unit dan begitu pun sebaliknya.

2. Koefisien regresi $(\beta) \mathrm{X} 2$ sebesar 0,318 memberikan arti bahwa kualitas layanan (X2) berpengaruh terhadap loyalitas pelanggan menginap pada cahaya swalayan Meureudu Kabupaten Pidie Jaya (Y). Hal ini menunjukkan bahwa setiap perubahan 1 satuan harga maka akan terjadi perubahan peningkatan sebesar 0,318 unit dan begitu pun sebaliknya.

\section{Uji Hipotesis}

Pengujian hipotesis ini bertujuan untuk melihat bagaimana pengaruh variabel 
Jurnal Sosial Humaniora Sigli (JSH)

p ISSN : 2615-3688

$e$ ISSN : 2716-0270

http://journal.unigha.ac.id/index.php/JSH

independen terhadap variabel dependen.Pengujian hipotesis ini terdiri atas uji hipotesis secara parsial (Uji T) dan uji hipotesis secara simultan (Uji F).

Adapun hasil dari pengujian tersebut juga akan di jelaskan.

\section{Uji Simultan (Uji F)}

Uji statistik $F$ pada dasarnya menunjukkan apakah semua variable independen yang dimasukkan dalam model mempunyai pengaruh secara bersama-sama terhadap variabel dependennya. Hasil uji $F$ dapat di lihat padatabel berikut:

Tabel 4.9

Hasil Perhitungan Uji F

ANOVA $^{b}$

\begin{tabular}{|c|c|c|c|c|c|c|}
\hline Mode & & $\begin{array}{l}\text { Sum of } \\
\text { Squares }\end{array}$ & df & $\begin{array}{l}\text { Mean } \\
\text { Square }\end{array}$ & $\mathrm{F}$ & Siq. \\
\hline \multirow[t]{3}{*}{1} & Regression & 109,080 & 2 & 54,540 & 67,853 &, $000^{2}$ \\
\hline & & 14,133 & 93 & & & \\
\hline & Total & 183,833 & 95 & & & \\
\hline
\end{tabular}

a. Predictors: (Constant), X2, X1

b. Dependent Variable: $Y$

Dari uji ANOVA atau $F$ test, di dapatkan angka signifikan (Sig) $(0,000)$ yang berada di bawah 0,05 dan angka Fhitung sebesar 67.853 dimana angka Fhitung lebih besar dari Ftabel sebesar 2,47. Hasil ini menunjukkan bahwa variable kualitas produk dan kualitas layanan berpengaruh secara bersama-sama terhadap loyalitas pelanggan pada cahaya swalayan Meureudu Kabupaten Pidie Jaya.

\section{Uji Parsial (Uji T)}

Uji $\mathrm{T}$ dilakukan untuk mengetahui pengaruh masing-masing atau secara parsial variabel independen (kualitas produk dan kualitas layanan) terhadap variabel dependen (loyalitas pelanggan). Sementara secara parsial pengaruh dari keiga variabel independen tersebut terhadap loyalitas pelanggan ditunjukkan pada tabel berikut:

Tabel 4.10

Hasil Perhitungan Uji T

\begin{tabular}{|c|c|c|c|c|c|c|c|}
\hline \multirow[t]{2}{*}{ Model } & \multicolumn{2}{|c|}{$\begin{array}{l}\text { Unstanda } \\
\text { rdized } \\
\text { Coefficie } \\
\text { nts }\end{array}$} & $\begin{array}{l}\text { Standar } \\
\text { dized } \\
\text { Coeffici } \\
\text { ents }\end{array}$ & \multirow[b]{2}{*}{$\mathrm{t}$} & \multirow[b]{2}{*}{$\begin{array}{l}\text { Si } \\
\text { g. }\end{array}$} & \multicolumn{2}{|c|}{$\begin{array}{l}\text { Collinearit } \\
\text { y Statistics }\end{array}$} \\
\hline & $B$ & $\begin{array}{l}\text { Std. } \\
\text { Erro } \\
r\end{array}$ & Beta & & & $\begin{array}{l}\text { Toler } \\
\text { ance }\end{array}$ & $\begin{array}{l}\text { VI } \\
\text { F }\end{array}$ \\
\hline $\begin{array}{c}1 \text { (Cons } \\
\text { tant) }\end{array}$ & $\begin{array}{l}2,2 \\
94\end{array}$ &, 931 & & $\begin{array}{l}2, \\
46 \\
5\end{array}$ & $\begin{array}{l}, 0 \\
1 \\
6\end{array}$ & & \\
\hline$\times 1$ & $\begin{array}{l}, 50 \\
2\end{array}$ & ,108 & ,495 & $\begin{array}{l}4, \\
65 \\
8\end{array}$ & $\begin{array}{l}0 \\
0 \\
0\end{array}$ & ,387 & $\begin{array}{l}2, \\
58 \\
6\end{array}$ \\
\hline$\times 2$ & $\begin{array}{l}, 32 \\
5\end{array}$ & , 109 & ,318 & $\begin{array}{l}2, \\
99 \\
2\end{array}$ & $\begin{array}{l}, 0 \\
0 \\
4\end{array}$ & ,387 & $\begin{array}{l}2, \\
58 \\
6\end{array}$ \\
\hline
\end{tabular}

a. Dependent Variable: $Y$

Pengaruh dari masing-masing variabel kualitas produk dab kualitas layanan terhadap loyalitas pelanggan dapat dilihat dari tingkat signifikansi (probabilitas). Kualitas produk, kualitas layanan dan lokasi mempunyai arah yang positif.

1. Pengaruh kualitas produk terhadap loyalitas pelanggan. Hasil uji t (parsial) antara variabel kualitas produk terhadap variabel loyalitas pelanggan menunjukkan nilai Thitung $(4,658)$ di mana nilainya lebih besar dari nilai Ttabel $(1,661)$, dan nilai signifikansinya sebesar 0,000 lebih kecil dari nilai probabilitas 0,05, maka variabel kualitas produk berpengaruh positif dan signifikan terhadap loyalitas pelanggan.

2. Pengaruh kualitas layanan terhadap loyalitas pelanggan. Hasil uji T (parsial) antara variabel kualitas layanan terhadap loyalitas pelanggan menunjukkan nilai Thitung $(2,992)$ di mana nilainya lebih besar dari nilai Ttabel $(1,691)$ dan nilai signifikansinya sebesar 0,000 lebih kecil dari nilai probabilitas 0,05 , maka variabel kualitas layanan berpengaruh positif dan signifikan terhadap loyalitas pelanggan.

Dari hasil yang dipaparkan di atas, dapat disimpulkan bahwa variabel independen $(\mathrm{X})$ memiliki pengaruh positif dengan tingkat signifikan masing-masing terhadap variabel dependen (Y).Nilai koefisien regresi keempat variabel 
independen maka nilai variabel kualitas produk $(4,658)$ lebih besar jika dibandingkan dengan nilai veriabel lainnya.

\section{Pembahasan}

Variabel kualitas produk berpengaruh positif dan memiliki pengaruh yang paling dominan terhadap loyalitas pelanggan dengan koefisien regresi sebesar 0,495, Berdasarkan data responden dari ketiga indikator pertanyaan yang diajukan, dapat dilihat bahwa responden lebih dominan memberi tanggapan setuju. Sesuai dengan Zeithaml (2008:89) yang berpendapat bahwa kualitas produk merupakan hasil penilaian pelanggan atas keunggulan atau keistimewaan layanan secara menyeluruh. Bila penilaian yang dihasilkan merupakan penilaian yang positif, maka kualitas layanan ini akan berdampak pada terjadinya loyalitas.

Variabel berikutnya adalah variabel kualitas layanan berpengaruh positif dengan koefisien regresi sebesar 0,318. Berdasarkan data responden dari ketiga indikator pertanyaan, dapat dilihat bahwa mayoritas responden memberi tanggapan setuju dari beberapa indikator pertanyaan.Hal ini membuktikan bahwa para pelanggan cahaya swalayan Meureudu Kabupaten Pidie Jaya menganggap bahwa kualitas layanan yang disediakan swalayan baik.

Menurut Tjiptono (2006:8) Persepsi yang di peroleh dari interaksi pelanggan dengan kualitas layanan berpengaruh terhadap kualitas jasa tersebut dimata pelanggan. Semakin baik kualitas jasa di mata konsumen, maka akan semakin besar kecenderungan konsumen tersebut untuk menggunakan jasa perusahaan tersebut.

Hal ini sesuai dengan penelitian Menurut Heizer (2001:6) kualitas produk dan kualitas layanan mempunyai kekuatan utuk mensukseskan ataupun menghancurkan strategi perusahaan.Oleh karena itu, penyedia jasa harus benar-benar mempertimbangkan, menyeleksi dan memilih lokasi yang responsif terhadap kemungkinan perubahan ekonomi, demografis, budaya, persaingan, dan peraturan di masa mendatang.Lokasi yang strategis merupakan salah satu alasan seseorang mengunjungi cahaya swalayan Meureudu Kabupaten Pidie Jaya.

\section{Kesimpulan}

Berdasarkan hasil penelitian yang di lakukan, maka dapat diambil kesimpulan antara lain sebagai berikut:

1. Berdasarkan hasil uji $\mathrm{t}$ (parsial) antara variabel kualitas produk terhadap variabel loyalitas pelanggan menunjukkan nilai Thitung $(4,658)$ di mana nilainya lebih besar dari nilai Ttabel $(1,661)$, dan nilai signifikansinya sebesar 0,000 lebih kecil dari nilai probabilitas 0,05, maka variabel kualitas produk berpengaruh positif dan signifikan terhadap loyalitas pelanggan.

2. Berdasarkan hasil uji $\mathrm{T}$ (parsial) antara variabel kualitas layanan terhadap loyalitas pelanggan menunjukkan nilai Thitung $(2,992)$ di mana nilainya lebih besar dari nilai Ttabel $(1,691)$ dan nilai signifikansinya sebesar 0,000 lebih kecil dari nilai probabilitas 0,05 , maka variabel kualitas layanan berpengaruh positif dan signifikan terhadap loyalitas pelanggan.

3. Variabel kualitas produk berpengaruh positif dan memiliki pengaruh yang paling dominan terhadap loyalitas pelanggan dengan koefisien regresi sebesar 0,495, Berdasarkan data responden dari ketiga indikator pertanyaan yang diajukan, dapat dilihat bahwa responden lebih dominan memberi tanggapan setuju.

4. Berdasarkan Tabel dapat kita melihat bahwa nilai Cronbach Alpha untuk independent variable yaitu variabel Kualitas produk (X1) sebesar 0.881 atau $88,1 \%$, kualitas layanan (X2) sebesar 0.879 atau 87,9 dan untuk dependent variable yaitu Loyalitas pelanggan (Y) memiliki nilai cronbach alpha sebesar 0.882 atau $88,2 \%$. 
Jurnal Sosial Humaniora Sigli (JSH)

p ISSN : 2615-3688

$e$ ISSN : 2716-0270

http://journal.unigha.ac.id/index.php/JSH

\section{Saran}

Adapun saran-saran yang di harapkan dalam penelitian ini adalah sebagai berikut:

1. Kepada pemilik cahaya swalayan Meureudu Kabupaten Pidie Jaya agar dapat dijadikan sebagai bahan informasi dan bahan perbandingan dalam meningkatkan keunggulan swalayan tersebut.

2. Bagi konsumen agar dapat membandingkan kualitas pelayanan, fasilitas dan lokasi sehingga menjadi suatu alat pengambilan keputusan untuk pada cahaya swalayan Meureudu Kabupaten Pidie Jaya

3. Bagi mahasiswa agar dapat menjadi bahan kajian dan menambah bahan di perpustakaan agar dapat digunakan oleh pihak-pihak yang berkepentingan.

\section{DAFTAR PUSTAKA}

Aritonang, Irianton. 2013. Memantau dan Menilai Status Gizi Anak. Yogyakarta: Leutika Books.

Augusty Ferdinand, 2011, Metode Penelitian Manajemen, Badan. Penerbit. Universitas Diponegoro Semarang.

Bob Sabran, 2012, Manajemen Pemasaran, penerbit erlangga.

Buchari Alma, (2011), Manajemen Pemasaran dan Pemasaran Jasa, Cetakan. Kesembelian, Alfabeth, Bandung.

Fandy, Tjiptono. 2011. Service Management Mewujudkan Layanan Prima. Edisi. 2. Yogyakarta:

Andi 2013, Prinsip-prinsip Total Quality Service, Yogyakarta: Andi Offset.
Garvin, David A.2016. alih bahasa Fandy Tjiptono, Strategi. Pemasaran. Yogyakarta.

Ghozali, Imam. 2009. "Aplikasi Analisis Multivariate dengan Program SPSS “. Semarang : UNDIP.

Gilbert A, 2013, Dasar-Dasar Riset Pemasaran, Jakarta, Penerbit: Erlangga.

Griffin. 2013. Perilaku Organisasi. Jakarta: Salemba Empat.

Hidayat, 2013. Analisis Pengaruh Harga, Kualitas Produk, Dan Kualitas Layanan Terhadap Kepuasan Pelanggan (Studi Pada Waroeng Spesial Sambal Cabang Lampersari Semarang)", Skripsi Program Sarjana Fakultas Ekonomika Dan Bisnis Universitas Diponegoro.

Kartajaya, Hermawan. 2013. Positioning, Diferensiasi, dan Brand. Jakarta: PT. Gramedia Pustaka.

Kasmir. 2008. Bank dan Lembaga Keuangan Lainnya. Jakarta: PT. Raja. Grafindo Persada.

Keller, Kevin Lane. 2010. Manajemen Pemasaran. Jilit 1, Edisi. Ketiga belas.Jakarta : Erlangga.

Kotler, dan Keller. 2012. Manajemen Pemasaran. Edisi 12. Jakarta: Erlangga.

Kotler, Philip.2011. Manajemen Pemasaran di Indonesia: Analisis, Perencanaan,. Implementasi dan Pengendalian. Jakarta : Penerbit Erlangga. 
Jurnal Sosial Humaniora Sigli (JSH)

p ISSN : 2615-3688

$e$ ISSN : 2716-0270

http://journal.unigha.ac.id/index.php/JSH

2013. Manajemen Pemasaran, Jilid Kedua, Jakarta: Erlangga.

Lupiyoadi, (2012), Manajemen Pemasaran Jasa Teori dan Praktik, Jakarta: Salemba Empat.

Moleong, L.J. (2011). Metodologi Penelitian Kualitatif Edisi Revisi. Bandung: PT. Remaja Rosdakarya.

Parasurama. 2009. Influence of Suctomer Satisfaction on Servicde Quality and Trust Relationship in Malaysian Rural Tourism. Business and Management Quarterly Review, 4(2), 12-25, 2013.

Sangadji, E.M., dan Sopiah. 2013. Prilaku Konsumen: Pendekatan Praktis. Disertai:Himpunan Jurnal Penelitian. Yogyakarta: Penerbit Andi.

Stanton (2011.Dasar-dasar Pemasaran, Edisi ke tujuh, Jakarta: Erlangga jilid ke-1.

Sugiyono, 2009, Metode Penelitian Kuantitatif, Kualitatif dan R\&D, Bandung : Alfabeta.

2011. Metode Penelitian Kuantitatif, Kualitatif dan R\&D. Bandung: Afabeta.
2014. Metode Penelitian Pendidikan Pendekatan Kuantitatif,. Kualitatif, dan R\&D. Bandung: Alfabeta.

Sunarto. 2010. Pakematik Strategi Pembelajaran Inovatif. Berbasis TIK.Jakarta : PT Elex Media Komputindo.

Supomo (2010. Analisis Pengaruh Loyaliats Produk, Kualitas Pelayanan, Desain Produk, Harga dan Kepercayaan terhadap Loyalitas Pelanggan Indosat IM3 pada Mahasiswa Fakultas Ekonomi Universitas Diponegoro Semarang. Tesis (tidak dipublikasikan). Semarang: BPFE Undip.

Zeithaml, V.A., M.J. Bitner, D.D. Gremler.2012. Services Marketing: Integrating Customer Focus Across the Firm6thed. Mc. Graw-Hill. Boston. 